\title{
TECHNOLOGY FOR MANUFACTURING NATURAL RUBBER LATEX BONDED COMPOSITES FROM LIGNOCELLULOSIC BASED ECO. MATERIALS AND AGRICULTURAL WASTE
}

\author{
Shanthi Illangasinghe and $M G M U$ Ismail \\ Industrial Technology Institute
}

In view of timber shortage and the need to conserve forest resources, a research is being carried out to utilize lignocellulosic materials as wood chips, saw dust, bamboo fiber and agricultural waste products as rise husk in making a low cost construction material as an architectural composite. Locally available natural rubber latex is used as the binder. The consideration being given to ecological factors to maintain and review the forest resources.

The results indicated that the mechanical properties of composites were improved with coir fibre, pine needles and bamboo strips. Solid products having high strength were prepared by hot-pressing the fibre/compounded latex mixture in a mould at $160{ }^{\circ} \mathrm{C}$ and at $100 \mathrm{Mpa}$ for 10 minutes. The boards can be manufactured in various densities and thickness to suit a wide range of applications.

This type of composite boards can be used as wall paneling, doors, windows, furniture, tabletops, ceiling, partitions, etc. They have very good mechanical and physical characteristics as strength properties, screw and nail holding capacity, dimensional stability. Specially Rise husk composite board have distinctly advantages properties as termite and rodent resistance, decay resistance, fire, water and chemical resistance, when compared to wood particle boards and other panel materials and it is an environmental friendly product.

Proceedings of the Ninth Annual Forestry and Environment Symposium 2003 of the Department of Forestry and Environmental Science. University of Sri Jayewardenepura, Sri Lanka 